\title{
KAZAK “MUŃLIQ-ZARLIQ” DESTANINDA BİR DEV ANA TİPİ: MISTAN KEMPİ
}

[Araştırma Makalesi-Research Article]

\begin{abstract}
Geliş Tarihi: 24.12.2019
Kabul Tarihi: 17.03.2020

$\ddot{O} z$

Kazak Türkleri, diğer Türk boyları gibi binlerce yıllık tarihi gelişim içerisinde sözlü olarak yaylan eserlerden en önemlisi sayllan destanları nesilden nesile aktarmıșlardır. Kökleri çok eski zamanlara dayanan halk edebiyatı örneklerinden biri "Muńlıq-Zarlıq" destanıdır. Bu anlatı, Sır Derya havalisinde, Oğuz-Kıpçak zamanında (XI-XII. asırlar) ortaya çıkmıştır. XIX. yüzyıla kadar Kazak Türkleri arasında sözlü bir şekilde, sonradan nazım ve nesir karışımı halinde yazlya geçirilerek hikâye-destan ya da arkaik destan olarak varlığını devam ettirmiştir.

Bu çalıșmanın temel amacı destandaki köklü mitolojik unsurlardan biri olan Mıstan Kempir tipinin karakter özelliklerini açılklamak, bu tiple ilişkili motifleri tespit etmek ve Yalmavuz (Kz. Jalmauız) tipi ile varsa benzer yönlerini veya farklılıklarını ortaya koymaktır. Çalışmanın giriş kısmında destan kavramı hakkında kısa bilgi verilmiş olup "Muńlıq-Zarlıq" destanının konusu anlatılmıştır. Makalenin ana kısmında metinde Mıstan Kempir tipinin geçtiği örneklere yer verilerek, örneklerden Mıstan ile ilgili motif ve epizotlar incelenmiștir. Makalede destanın Kiril harfleriyle neşredilmiş "Hikayet Risale-i Muńlıq-Zarlıq" varyantı ele alınmıştır.
\end{abstract}

Dilyaram AYUPOVA*

Anahtar Kelimeler: Kazak Destanı, Muńlıq-Zarlıq Destanı, Mistan Kempir, Jalmauı/Yalmavuz, Şaman/Kam.

\section{“MISTAN KEMPIR" - ONE OF THE TYPE OF OGRESS IN THE KAZAKH “MUŃLIQ-ZARLIQ” EPIC}

\begin{abstract}
The Kazakh Turks like other Turkic-speaking ethnic groups have created the most important epics, which had been spreading verbally from the generation to the generation. One of the brightest examples of folk literature, which has its roots in antiquity, is the epic "Munlık-Zarlık". This epic occurred in the region of Sir Derya at the period of the Oguz-Kipchak (11-12th centuries). By 19th century the epic has been continued its existence verbally and later as the mixture of poetry and prose of the story-epic or of an archaic epic among the Kazakh Turks.

The main purpose of this study is to explain the character of the Mistan Kempir, who is one of the deep-rooted mythological creature in the epic. Also the study identifies motifs associated with this type of creature and reveals similar aspects or diffErences connected with the Yalmavuz. In the introduction part of the study, is given a brief information about epic concept and explained the point of "Munlı-Zarlı" epic. In the main part of the study, are examined motifs and episodes related to Mistan Kempir by giving examples of it in the text. The study based on the "Hikayet Risale-i Munlık-Zarlı" variant of the epic, published with Cyrillic letters.
\end{abstract}

Keywords: The Epic of the Kazakh, The Epic of Munlık-Zarlık, Mistan Kempir, Jalmauiz/Yalmavuz, Shaman/Kam.

\footnotetext{
* Yüksek Lisans Mezunu, İstanbul Üniversitesi, Türkiyat Araştırmaları Enstitüsü, e-posta: dilyaram.ayupova@gmail.com Orcid: 0000-0003-4384-6199
} 


\section{Giriş}

Kazak folklorunda destanların çok önemli bir yeri vardır. Çünkü destanlar kültürün en berrak aynalarıdır. Destanlar, tarihin derinliklerinden ipucu veren ve olayları belli bir tarzda motiflerle anlatan köklü eserlerdir.

Faruk Kadri Timurtaş, destan kavramını şöyle açıklar: "Destanlar tarihten önce veya tarihin başlangıcı sırasında bir milletin geçirdiği maceraları, yetiştirdiği kahramanları; tabiat, kâinat ve cemiyet hadiseleri hakkında düşündüklerini ve bunlar karşısında aldığı vaziyetleri anlatan kahramanlık efsane ve hikâyeleridir" (Timurtaş, 2005: 22).

Kazak aydını Çokan Valihanov'a göre destan metinlerinin ilk şekilleri XIII. yüzyıldan başlamak üzere XV-XVI. yüzyıllarda ortaya çıkmıştır. Ferhat Tamir'in (2011: 71) belirttiğine göre, Çokan Valihanov'un bu iddiaları, tüm Kazak destanları için geçerli olmasa bile, birçoğu için geçerli sayılmaktadır. Rus folklorcusu A. K. Borovkov'un görüşleri açısından bakılınca Oğuz destanları IX-X. yüzyıllarda, Kıpçak destanları ise XIV-XV. yüzyıllarda ortaya çıkmıştır. Kıpçak destanları içine dâhil edilen Kazak destanlarının Nogay devrinde şekillenmeye başladığı vurgulanmaktadır (Aça, 2002: 49-50). Şüphesiz Kazak destanlarının temelinde ortak Türk kökeninden gelen Kıpçak, Oğuz, Nogay, Uysun, Kanlı, Kerey vb. boyların tarihi yer almaktadır. Halk edebiyatının bu tür köklü, genel Türk folklor geleneğiyle yoğrulan yapıtlarından biri "Muńlıq-Zarlıq" destanıdır.

Farklı şekillerde tanımlanan "Muńlıq-Zarlıq" destanı, Iskak Düysenbayev tarafından "Qazaqtı́n Liro-Eposı" (Kazak Lirik Destanı) adlı çalışmasında doğu edebiyatından gelen kıssalar olarak lirik destanlar (Kz. liro-epostar) grubunda gösterilmiştir. Ayrıca destan, Kazak bilim adamlarından Rahmankul Berdibayev'in "Qazaq Eposı" (Kazak Destanı) eserinde arkaik destan, Avelbek Konıratbayev'in "Qazaq Eposı jane Türkologiya” (Kazak Destanı ve Türkoloji) adlı eserinde ise masalsı destan başlığı altında incelenmiştir (Aça, 2002: 32, 36, 50). Kahramanlık destanı olarak da kabul edilen "Muńlıq-Zarlıq" destanı, X. yüzyılda Orta Asya'nın Sır Derya havalisinde, Oğuz-Kıpçak döneminde meydana gelmiştir (Abilulı, 2013: 5). Anlatının Sır Derya havalisinde ortaya çıtı̆̆ı, destanda adı geçen yer-su ve kişi adlarından hareketle tespit edilmiştir. Bu destan sadece Kazak Türklerinin değil aynı zamanda Orta Asya Türk soylu halklarının da eski devirlerden kalmış ortak mirası sayılır. Türk Dünyası'nın farklı coğrafyalarında ve farklı Türk halkları arasında değișik başlıklar altında varlığını devam ettiren "Muńlıq Zarlıq" gibi anlatılar Türk kültürünün ortak bir kaynaktan beslendiğinin açık bir göstergesidir. Örneğin Uygur halk edebiyatı örneklerinden "Çın Tömür Batur ve Mehtumsula" (İnayet, 2004: 143-166) masalının aynı konulu olmasa da bazı tip (Mıstan, Yalmavuz gibi), motif ve epizotları açısından "Muńlıq-Zarlıq" destanı ile benzerlik gösterdiğini belirtmekte fayda vardır.

"Muńlıq-Zarlıq" destanı Kazak sözlü edebiyatının önemli eserlerindendir. 1895 yılında sözlü gelenekte nazım ve nesir karışımı halinde yaşayan destanın nüshaları yeniden yazılarak Arap harfleriyle "Hikayet Risale-i Muńlıq-Zarlıq" adıyla yazar Jüsipbek Şayhulislamov tarafından yayımlanmıștır. Eser, 1971 senesine kadar on baskı yapmıștır (Subhanberdina, 1994: 368). Destan, han ailesi, insanlık, adalet, iyilik ve kötülüğün mücadelesi gibi konuları esas almaktadır. Zamanla tür değişimlerine uğramış olsa da ana olay örgüsünü muhafaza etmiştir. Anlatıya İslamî unsurların girmesi neticesinde bazı motif ve epizotların da değişime uğradığı fark edilmektedir.

J. Şayhulislamov destandaki olayların Nogay yurdunda gerçekleştiğini şu şekilde aktarmaktadır: "...On san Noğay elınde Şanşar han attı hanı bar. Ğadalatşı han eken, qayırı tigen jahanğa. Bır perzentke zar bolıp, alpıs qatın alıptı..."1 (Akan, 2008:11).

\footnotetext{
1 “...On bin Nogay yurdunun Şanşar adlı hanı var. Adaletli han imiş, hayrı dokunmuş cihana. Bir çocuk arzusuyla
} altmış kadınla evlenmiş." 
Destanın olay örgüsüne göre Nogay yurduna altmış yaşında olan Şanşar adlı bir han hükmetmiştir. Altmış kadınla evlenmesine rağmen hanın hiç çocuğu olmamıştır. Bir gün Şanşar Han'ın rüyasına Hazret-i Hızır² girmiş ve "Bir güzelle evlen, sonra kız ve erkek çocuk sahibi olacaksın!" diye ayan etmiștir. Çocuksuzluk derdiyle yașayan han, günün birinde Jaudır adlı balıkçının Qanşayım isimli kızıyla evlenir. Daha sonra Qanşayım bir kız, bir oğlan dünyaya getirir, bu durum hanın diğer altmış hanımının kıskançlığını uyandırır. Dolayısıyla altmış kadının emriyle doğum sırasında bayılan Qanşayım'ın çocuklarını, Mıstan Kempir (cadı/ihtiyar kadın) uzaklara kaçırır. Çocukların yerine de iki köpek yavrusunu bırakır. Cadı, çocukları Qazar (Ğazar) nehrine (Hazar denizi) ${ }^{3}$ atmak isterken Gayp Eren Kırk Şilten (Kz. Ğayıp Eren qırıq Şilten) ${ }^{4}$ çocukları kurtarır ve oğlana Zarlıq, kıza Muńlıq isimlerini verir. 0 , çocukları dağa götürür, başlarına bir geyiği anne olarak verir. Hanımının köpek yavruları doğurduğunu duyan han ise onu ağır bir șekilde cezalandırmak ister ama Qanşayım Gayp Eren Kırk Şilten'in yardımıyla cezadan kurtarılır. Buna rağmen Şanşar Han, hanımını köpek yavrularıyla beraber yerin yedi kat altındaki ıssız adaya bırakır. Bu arada anne ve baba sevgisini göremeyen Muńlıq ile Zarlıq hızla büyür. Zarlıq çok güçlü kahraman olarak, Muńlıq da maharetli güzel bir kız olarak yetişir. Aradan zaman geçip çocukların ölmediğini öğrenen cadı, Muńlıq ile Zarlıq'ı birbirinden ayırmak ister. Cadı, sinsi planını gerçekleştirmek için Muńlıq'ı Gayp Eren kılığına girerek aldatır ve kardeşi Zarlıq’ı Kalmuk hanı Külmes'in yurduna göndermesi için ikna eder. Böylece Zarlıq, uzun bir yolculuğa çıkar ve Kalmuk ordusuyla savaşır. Neticede Külmes Han'ı korkuya düşüren, aynı anda hanın güvenini kazanan Zarlıq'a, han, Quralay adlı kızını verir. Zarlıq, Kalmuk yurdundayken Quralay'ı kaçıran Karadáu (Kara dev) ile mücadele edip onu koruyan Gayp Erenlerin yardımıyla devi yenip Külmes Han'ın verdiği armağanlarla kardeşi Muńlıq'ın yanına döner. Bu arada ıssız adada azap ve ıstırap çeken Qanşayım, bir gün rüyasında Hazret-i Hızır ve Gayp Eren'i görür. Böylece çocuklarının yaşadığını ve cadının onları kaçırdığını öğrenir (Akan, 2008: 11-64). Şanşar Han ise günün birinde ava çıktığında altın başlı ve gümüş gövdeli bir geyiğe rastlar ve onu öldürmekten vazgeçer. Lakin geyiği diri olarak yakalamak isteyip onu takip etmeye başlar. Aynı zamanda hanın oğlu Zarlıq da bu geyiğin peşine düşer. Aslında o geyik, baba ile oğlu peşine takarak onları karşılaştırma niyetinde olan Gayp Erenlerden biridir (Özcan, 2011: 35). Böylece Hazreti Hızır ile Gayp Eren Zarlıq'a Şanşar Han'dan bahseder. Babasını bulan oğlan ona bütün gerçekleri anlatır. Nihayetinde Şanşar Han, büyük pişmanlık ile Qanşayım'ı yer altındaki adadan azat eder ve onun çocuklarıyla kavuşmasını sağlar. Mıstan Kempir ise hak ettiği cezasını çeker. Şanşar Han, padişahlığı kendisinden daha güçlü ve adaletli olan oğlu Zarlıq'a bırakır, yıllar sonra da kendi eceli ile vefat eder (Akan, 2008: 6574).

\section{Dev Ana Tipi: Mıstan Kempir}

Destanda yer alan olumsuz aynı zamanda önemli mitolojik kahramanlardan biri "Mıstan Kempir" dev ana tipidir. 0, insanların yolundan şaşması, han adaletinin sarsılması, başkahramanların zor hayatı gibi tüm kötülüklerin sorumlusudur. Genelde devler olumlu ve olumsuz olmak üzere ikili karaktere sahiptir. Ama cadının olumsuz yönleri daha ön plandadır. 0 , paraya düşkün, dilini çok iyi kullanan, kandırma kabiliyeti yüksek, zalim ve hilekâr ihtiyar bir kadındır.

\footnotetext{
2 Hazret-i Hızır (Kz. Qızır/Qıdır Ata), Kazak folklorunda beyaz elbiseli gezgin, aksakal kılığındaki evliya, insanoğlunun yardımcısı ve koruyucusu olarak bilinmektedir. Bk. (Akan, 2008: 289).

3 Eski Türkler'de Hazar Denizi ve Aral Gölü civarında cesetler çoğu kez nehre atılırdı. Bk. (Roux, 2015: 107).

4 Gayp Eren Kırk Şilten, İslam inanışına göre insanları koruyup kollayan görülmeyen gizli yaratıklara verilen isimdir. "Şilten" tabiri Farsça kökenli olup "kırk kişi" anlamına gelmektedir. Bu tabir Kazak dilline fazladan "kırk" sözcüğü eklenerek girmiştir. "Gayp Eren" ise "Kırk Şilten" kavramının eş anlamlısı olarak ifade edilmektedir. Gayp, Arapça görülmeyen ve bilinmeyen anlamına gelir. Bk. (Kortabayeva, 2019: 291). Eren ise Eski Türkçe'de "er" kelimesinin çoğulu olup Farsça “erkek, yaren, yoldaş" manasına gelir. Bk. (Uludağ, 1995: 294).
} 
Destandaki Mıstan Kempir'in taşıdığı karakter özellikleri şu şekildedir: Dev ve ihtiyardır (300 yaşında), ailesi yoktur, kurnaz ve hilecidir, aldatıcı ve kandırıcıdır ve büyü yapabilme kabiliyetine sahiptir. Genel olarak bakıldığında bazı özellikleri hariç onun insanlardan çok da farkı yoktur.

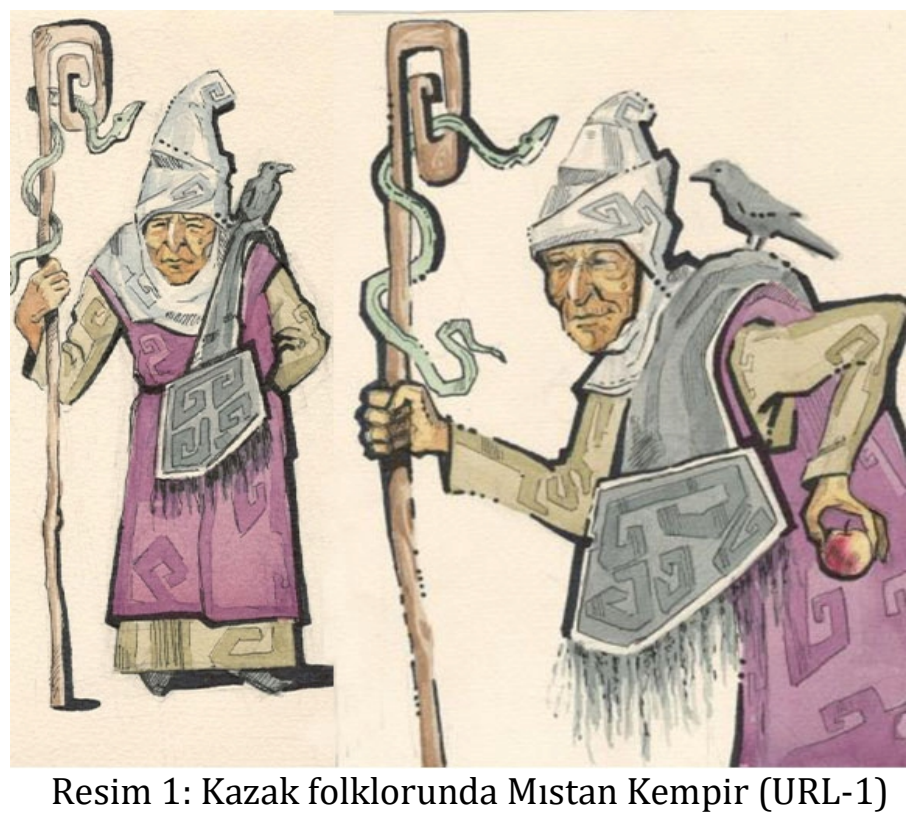

Mıstan Kempir (Kırg. Mastan Kempir) sözcügüne Kırgız-Rus sözlüğünde şu şekilde açıklama verilmiştir: ihtiyar kadın kılığındaki şeytani varlık; masal kahramanı olan hileci ihtiyar kadın (Yudahin, 1985: 20). Onun ihtiyar olduğu ve 300 yaşa geldiği Şanşar Han'ın Barın adlı vezirinin söylediği aşağıdaki mısralardan anlaşılmaktadır:

“- Mistan Kempir anamız,

Bız de sizdıń balańız...

...Üş̧ jüz jasqa barıpsıń,

Düniyeniń tübin şalıpsıń...5” (Akan, 2008: 25-26). Dünyanın dibine kadar gitmişsin...”

“- Mistan Kempir annemiz,

Biz de sizin yavrunuz...

Üç yüz yaşa gelmişsin,

Cadı bedeninin büyük ve korkutucu olması ise şu satırlardan fark edilir: "Ol jalmauız Kempirdiń auzına da ekı kışı ...(argo) de ekı kısı at-tonımen siyuşı edı. Qırıq jıgıt qırıq jaqqa qaştı" (Akan, 2008: 26). ${ }^{6}$ Yukarıda verilen mısralardan görüldüğü üzere, Mıstan Kempir kızdırıldığında tipin olumsuz yönleri daha belirginleşerek Yalmavuz tipi ile özdeşleştirilmektedir. Demek ki insan kılığındaki Mıstan Kempir, yaptığı kötülükler yüzünden Yalmavuz olarak adlandırılabilir ya da Yalmavuz'un kendisine dönüșebilir. Mıstan Kempir'in Yalmavuz ile benzer özellikleri olduğu gibi farklılıkları da mevcuttur.

Alimcan İnayet (2010: 19-20), Yalmavuz'un çeşitli adlarla (cadı, cadıger, Mıstan Kempir) anıldığını belirterek, Yalmavuz tipinin karakteristik özelliklerini şöyle sıralamaktadır: Dağ ve mağaralarda yaşar, şekil değiştirebilir, insan kanı emer, ${ }^{7}$ insan ve sürü etini yer, ruhunu

\footnotetext{
5 "Düniyeniń tübin şalıpsın”" demek, yani görünmeyen dünyanın dibine varmak ihtiyar kadının uzun bir süre yaşamış ve çok şey görmüş olduğu anlamına gelmektedir.

6 "O Yalmavuz'un ağzına da iki kişi, arkasına da atlı iki kişi sığarmış. Kırk yiğit kırk tarafa kaçtı."

7 Uygur Türklerinde Yalmavuz'un insan kanını içme motifiyle ilişkilendirilen sineklerin nasıl ortaya çıktığına dair "Sinek nasıl ortaya çıktı?" adlı bir masal mevcuttur. Anlatıya göre sinekler Yalmavuz'un leşinden peyda olmuştur. Bk. (İnayet, 2010: 157-162).
} 
başka yerlerde saklayabilir, çok başll, dişi cinsiyetli ${ }^{8}$ ve hileci yaratıktır. Mıstan Kempir'in ise Yalmavuz'un kardeşi olduğu iddia edilmektedir. Bu durum, iki tipin mitolojik kökeninin aynı yerde birleștiğini, zaman zaman birbirlerine karıștığını göstermektedir.

S. V. Dmitriyev (2009: 318), Kazak Türklerindeki Mıstan Kempir ile Kırgızlardaki Jalmauız Kempir, Özbeklerdeki Yalmaviz/Jalmaviz Kempir tiplerini aynı safta incelemektedir. A. N. Sidikov (2013: 36) da Yalmavuz ile Mıstan Kempir'i eş anlamlı olarak değerlendirmektedir. Lâkin Kazaklardaki "Mıstan Kempir” tabirinin Kırgızlar'da "Mastan Kempir”, Özbekler'de "Maston Kampir", Batı Sibirya Tatarları'nda "Muskortka" ve Uygurlar'da "Mistan" adlarıyla rastladığı da bilinmektedir.

\section{Mıstan Kempir İle İlgili Motifler}

\section{Büyü Yapan ve Hasta Bakan Mıstan Kempir Motifi}

Eskiden Türk boyları arasında büyü yapan kişilere "yalvi" ${ }^{9}$ denilmiştir. Yalvi (yalwi), büyü; yalvıcı/yalvci ise büyücüdür. Kaşgarlı Mahmud (1941: 33), bu tabire "sehire yalvi, yelpi, büyücüye de yalvıcı denir" şeklinde açıklık getirmiştir. Büyüye, şamanlıkta da büyük önem atfedilmektedir. Lakin Jean-Paul Roux'un (2015: 117) belirttiğine göre eski Türkler, yalvi büyüsü yapan yalvicilar ile Türkçe isimleri kam ${ }^{10}$ olan şamanları birbirinden ayırmışlardır. Eskiden kamların görevleri ağır hastaları iyileştirmek, her türlü ruhlarla karşılaşıp onların kötülüklerini geri çevirmek, ölülerin ruhlarını öteki dünyaya göndermek, avcılıktaki şanssızlıkları gidermek ve ailenin saadetini sağlamak için törenler düzenlemek olmuştur. Şaman ile kam eş anlamda kullanılmıştır. Kam, erkek ve kadın olabilir. Kadın kamlar ise daha etkilidir. Şaman inanışının gereklerine kadınlar daha çok uymaktadır. Bu yüzden ulu kamların kadın olduğu bilinmektedir. Bu da şamanlığın anaerkil dönemin ürünü olduğunu göstermektedir (Kalafat, 2004: 48, 100, 122-124). Kadın şamanlar "utagan, udagan, ubakan, utugan" olarak adlandırılır. Utagan, ateşi ${ }^{11}$ koruyan anlamına gelmektedir (Güngör, 2010: 325).

Bu bağlamda metin analizi yapılırken yalvıcı ve kamların taşıdığı büyü yapma, kılıktan kılığa girme, hasta bakma ve tedavi etme gibi özellikler Mistan Kempir tipinde de fark edilmektedir. Örneğin Mıstan Kempir, doğum sırasında Qanșayım’ı büyü yaparak ${ }^{12}$ baygın hale düşürür. Kadının karnını çeker ve hemen gümüş saçlı bir kız ve altın saçlı bir erkek çocuğu doğurtur ve yerine iki köpek yavrusunu getirir. Çocuklardan kurtulduktan sonra da Qanşayım'ın kalbinin yavaş attığını sezen cadı, tekrar aynı büyüyü uygulayıp Qanşayım'ı uyandırır (Akan, 2008: 19-21). Keza, cadı mağarada Muńlıq ile buluştuğu an da büyü yapıp kaybolur: "Bu sözdı qızğa Kempir aytıp saldı, siqırmen duğa oqıр ğayıp boldı. Pırım eken desın dep ol jalmauız, közıne körınbestey ayla qıldı." (Akan, 2008: 29).13

V. N. Basilov'a (1980: 439) göre şamanların bazı görevlerini üstlenen bu tip, kötülügün başlangıcıdır. Kazak folklorcusu Seyit Kaskabasov (2009: 74) ise Mıstan Kempir hakkında şöyle bir açlklamada bulunmuştur: "Onun Yalmavuz gibi sihir yapabilme kabiliyeti yok. $O$ genellikle sinsice, el altından hareket eder ve kahramanlara karşı hilelere başvurur". Bu düşünceyle hareket edilirse, Mıstan Kempir'in çoğunlukla masalsı destanlarda rastlanan

\footnotetext{
8 Alimcan İnayet $(2010$ : 65, 69), eserinde Yalmavuz'un genelde çift cinsiyetli olduğunu, dişi cinsiyetliyken de kızları kaçırdığını belirtmiştir.

9 "Yalmavuz" ve "yalvi" kelimelerin aynı kökten türemiş olma ihtimali vardır.

10 Kazak dilinde bu kamlara "baksı, bahşı, karamurt, darger" denilmektedir.

${ }^{11}$ Ateş ve duman, Yalmavuz ile Mıstan Kempir'in da kullandığı önemli unsurlardandır.

12 Destanda "betine dem salu" (kelimesi kelimesine çeviri: yüzüne nefes vermek) olarak geçmektedir.

13 "Bu sözü kıza cadı söyledi, sihirle dua okuyup kayboldu. Pirim zannetsin diyerek o Yalmavuz, (kızın) gözüne görünmeden hile yaptı."
} 
Yalmavuz tipinin zamanla gücünü yitirmiş ama büyücülük karakterini iyi korumuş ve biraz insanlaştırılmış şekli olma ihtimali yüksektir.

\section{Cadı ve Su Motifi}

$\mathrm{Su}$, cadıya ait unsurlardan biridir. Böylece cadının su altı dünyası ile belli bir temas halinde olduğu düşünülebilir. Kazak folklorunda su altı (yer altı) dünyası, ölüler padişahlığı olarak bilinmektedir. Yalmavuz da Mıstan da bu padişahlığın temsilcileri sanılmaktadır (Kaskabasov, 2009: 73). Dolayısıyla cadı, Muńlıq ile Zarlıq'ı kaçırdığında onları suya atarak ölüme terk etmek ister. Cadının çocuklara acıdığı ifade edilse de açgözlülüğü merhametinden baskın olduğu aşağıdaki mısralarda açık görülmektedir ve şu şekilde aktarılmaktadır:

“...Ekı asıl sultanım,

Qanıńdı jüktep baramın

Alpıs tabaq tillá üşın

Bu bes kündık düniyede.

Tastayın desem bu suğa,

Senderdı közım qimaydı,

Tastamaymin desem de,

Alpıs "anań" bolmayd.

Barğın, balam, Allağa,

Razı bolğın qazağa." (Akan, 2008: 19).
“...İki asil sultanım

Kanını yük yaptım

Altmış tabak altın için

Bu beş günlük dünyada.

Atmak istesem de bu suya,

Sizi gözlerim klyamıyor,

(Suya) atmayayım desem de,

Altmış "annen" olamaz.

Gidin, yavrum, Allah'a

Razı olasin kazaya."

$\mathrm{Bu}$ mısralardan anlaşıldığı üzere paragöz Mıstan Kempir, altmış tabak altından vazgeçemeyeceğini altmış tane annenin çocukları rahat yaşatmayacağı bahanesiyle kendi hareketine mazeret bulmaya çalışır ve aniden dile gelip yalvaran çocuklarla konuşur. Neticede çocukları vurup ağlatır ve yakalanmaktan korkarak suya atar. Böylece, Mıstan Kempir için terazinin bir tabağında altın ve mal-mülk, ikincisinde insanlık ve sevap olduğunda, birincisinin ağırlıklı olduğu görülmektedir. Çünkü cimrilik, bencillik ve acımasızlık insan kılığındaki Mıstan'a has değişmeyen karakteristik özelliklerdendir.

\section{Danışman ve Hileci (Keskin Dilli) Mıstan Kempir Motifi}

Destanda Mıstan karakterinin han ve diğer karakterler üzerindeki etkisi analiz edildiğinde, Mıstan'ın yaşından, cesaretinden ve manevi gücünden ötürü han ailesi ve çalışanları tarafından ona bir nevi saygı gösterildiği fark edilmiştir. Örneğin Şanşar Han'ın altmış hanımı, hana Qanşayım'ın köpek yavrularını doğurduğunu nasıl duyuracağını bilemeden bu işi hana sözü geçen ve kimseden utanmayan Mıstan Kempir'e vazife eder. Mıstan da kabul görüp, durumu hana ağlaya ağlaya şöyle izah eder:

“- Atıńnıń basin tart, balam,

Ne dep otır qart mamań.

Qart mamańnı́n sözıne

Qulağın sal, ört balam,

Ğayıp bolsın sırlasıń.

Kepıl bolıp qız bergen

Jalğanşı eken Jaudır şal,
"Atının başını çek, oğlum,

Ne diyor yaşlı annen.

Yaşlı annenin sözüne

Kulak as, oğlum,

Gayp olsun sırdaşın.

Kefil olup kız veren

Yalancı iken Jaudır kart, 
Bu düniyede ońbasın,

Ońbasın demey ne deyın,

it balasin taptı ğoy

Qanşayımday joldasın..." (Akan, 2008: 22).
Bu dünyada iyi olmasın,

Lanet olsun demeden ne diyeyim,

Köpek yavrusunu doğurdu

Qanşayım gibi yoldaşın (yârın)..."

Danışman Mıstan Kempir motifi, cadının tüm suçları ortaya çıkana dek sık sık karşımıza çıkmaktadır. Mesela Şanşar Han avdayken dağda uyuyan altın saçlı bir çocuğu (Zarlıq) görüp ona sarılıverir. Şaşıran çocuk, babası olan kişiyi hemen iter. Zarlıq'ın gücünden korkan han, sarayına dönünce tahtına oturmak istemeyip dağın bile çocuğu olduğuna üzülür ve Allah'a yalvararak çok ağlar. Bunu işiten altmış kadın, Mıstan Kempir'in hanı teskin edip akıl vermesini buyurur. Cadı ise hanı şöyle sakinleştirir:

“- Aynalayın padişa,

Mistan anań kelıp tur,

Otırıp-dür qası́nda.

Senıń üşıı tögermın

Qan aralas jasımdi.

Ne qıladl, kelgende,

Bır kötersen basıńdl.

Tauğa da sen barasıń,
"Ey, padişahım,

Mistan annen geldi,

Oturuyor yanında.

Senin için dökerim

Kanlı gözyaşımı.

Ne olursun, geldiğimde,

Bir kere kaldırıversen başını.

Dağa da sen gidersin,

Perinin gördün evladını..."

Böylece cadı, tatlı tatlı konuşarak, yeri gelince de hileye başvurarak hanı teselli eder, sözlerine inandırır. Danışman görevini üstlenen ihtiyarın sözlerinin han için bu kadar önemli ve inandırıcı olması ilgi çekicidir. Çünkü cadının konuşmasından sonra Şanşar Han hemen başını kaldırır, üzüntüsünü unutur ve işlerine devam eder.

Destan örneklerinden görüldüğü gibi Mıstan Kempir'in başkalarını sözlerine inandırma özelliği üstündür. Destanda onun han ve yanındakilerini her seferinde "Ben sizin ananızım!" diyerek kandırdığı görülmektedir. Kötülük timsali Mıstan, Qanşayım'ın çocukları hakkındaki gerçeği öğrenmek isteyen han muhafızlarını tek sözüyle aldatır ve onları Qanşayım'ı idam etmeye sürükler: "- Men de patşanıń tıleuın tılep jürsem, sender mınanı aytasıńdar. Men nege hanğa qastıq qılayın. Bul sözbenen qırıq jıgıt Qanşayımdı darğa tarttı." (Akan, 2008: 26). ${ }^{14}$ Lakin Qanşayım, Gayp Erenlerin yardımıyla ölümden kurtulur. Üstelik cadı Zarlıq'ın yaşadığını öğrenir öğrenmez (nerden ve nasıl öğrendiği belli değil) haberi altmış kadına söyler. Onlar da altın karşılığına oğlanı öldürmesini buyurur. Böylece cadı dağ gezip yürürken, altı yaşar Muńlıq’ı görür. Mağaraya kaçıp kurtulan kızı kendisinin Gayp Eren olduğuna inandırır:

“...Tüzdegı men bır Ğayıp,...

...Sálem de, ağań tılımdı alsın deymın,

Elıne Külmes hannıń barsın deymın.

Toqsan kündık jolı bar arasınıń,
“...KIrdaki ben bir Gayp,...

...Selam söyle, ă̆abeyin sözümü dinlesin.

Yurduna Külmes Han'ın gitsin diyorum.

Doksan günlük yol vardır arasında,

14 "Ben de padişahın sağlı̆̆ını dilemekte isem, sizler bana lâf atıyorsunuz. Bu sözlerle kırk yiğit Qanşayım'ı asmaya kalkıştı." 
Altı ayda at-ton alıp kelsın deymın."

Altı ayda at ve kürk alıp gelsin diyorum." (Akan, 2008: 29).

Neticede dolandırıcı hareketleri ve hilelerine rağmen cadının gerçek yüzü, yaptığı kötülükleri ve düşmanlığı ortaya çıkar. Kaçtı̆̆ı yerden yakalanıp ağır cezalandırılır:

"Mistan qaşıp ketıptı,

Barın üázır quadı...

...Qulağın kesti quntitıp,

Murnin kestı şuntitıp,

Ekı közın ağızıp,

Qu basın koydı sımpitıp.

Küye jağıp betıne,

Tirseginen tiledl.

Bayterektıń basina

Salbıratıp ıledı... "(Akan, 2008: 73).
“Cadı kaçıp gitmiş,

Barın vezir kovalamış...

...Kulağını kesmiş küçültüp,

Burnunu kesmiş küçültüp,

İki gözünü akıtıp,

Başın koymuş sergiye

Kül sürüp yüzüne,

Baldırından dilmiş.

Kavağın başına

Ters sarkıtıp asmış..."

Muńlıq-Zarlıq destanındaki tarihi, mitolojik ve dini unsurların iç içe geçerek bir bütünlük sağlayarak varlığını koruyabilmesi destanın ne kadar eski zamanlara dayandığının bir göstergesidir. Destanın arkaikliğine dair taşıdığı özellikleri ve başlıca motifler olarak şunlar belirtilebilir:

- Ana kahramanlar zor duruma düşünce onların yardımına koşan sihirli güçlerin ortaya çıkması;

- Şekil değiştirme olgusu;

- Çocuksuzluk derdiyle yaşama olayı;

- Hanın evliyaları dolaşıp çocuk istemesi;

- Yaratıcıya yalvarma ve dua etme;

- Rüyada ayan etme;

- Kahramanın uzun yolculuğa çıkıp düşman güçleriyle ve çeşitli varlıklarla (dev) olan mücadelesi ve onları yenip muradına ermesi;

- Kahramanların birbirine kavuşması;

- Doğaüstü varlıklar (besleyen geyik, piriler, Gayp Eren Kırk Şilten) ve büyü (cadı büyüleri);

- Anaerkil devirden kalma bazı unsurlarla birlikte onun yerine geçen ataerkil döneme ait geleneklerin yer aldığı olayların görülmeye başlaması vs.

Anaerkil döneme ait unsurlardan olan Mıstan Kempir ve Yalmavuz tipleriyle ilgili ilim adamlarının görüşlerine dayanarak aşağıdaki varsayımlarda bulunmak mümkündür.

Alimcan İnayet'in (2010: 26) elde ettiği tespitlere göre: “Yalmavuz'un anaerkil dönemde yaşamış önemli bir tanrıça veya savaşçı kadının ruhu olması ve sonraki tarihi süreçte kötülenerek canavara, cine, şeytana veya deve dönüşürülmesi muhtemeldir." Yalmavuz, kamlar gibi çift cinsiyetli olabilir, şekil değiştirebilir, büyü yapabilir çünkü şamanın yarattığı 
bir tiptir. Bu ortak yönlerden yola çıkarak Yalmavuz tipinin kökeninin Şamanizm'le ${ }^{15}$ ilgili olduğu tespit edilmiştir (Öger, 2007: 220; İnayet 2010: 67).

Bu iddiaları folklorcu Şakir Ibrayev'in (1993: 69) şu ifadesi destekler niteliktedir: "Anaerkil dönemi sona erip, onun yerine ataerkil devri gelince kadınları sert düşman ve aşağılık kimse olarak gösterme mantığı vuku bulmuştur". Dolayısıyla Mıstan Kempir ve Yalmavuz tipleri ortaya çıkarak hep olumlu kahramanların karşısında durmuştur.

\section{Sonuç}

Mıstan Kempir tipinin Yalmavuz'un bir çeşidi ya da değişime uğramış türü ve devamı olduğu düşünülürse her iki tipin de kökü Şamanizm inancına dayandığı iddia edilebilir. Eğer eski mitlerde rastlanan kadın şamanlar Yalmavuz'un prototipi ise Yalmavuz da Mıstan Kempir'in prototipi olarak kabul edilebilir. Şüphesiz halk edebiyatı ürünlerinde yer alan Mıstan Kempir, Yalmavuz, albastı gibi kadın tipleri ve onlarla ilgili olağanüstü motifler, anaerkil dönemindeki güçlü kadın imajının folklordaki yansımasıdır. Ataerkil dönemin getirdiği yeniliklerle kadın şaman tipleri, tarih çağlarından geçerek esas insani özelliklerini yitirip destanlara yansıyan insan kılığına girmiş şeytani varlıkların ortaya çıkmasına neden olmuştur.

Hülasa Mıstan Kempir tipinin ataerkil dönemin bașlamasıyla ve Orta Asya Türklerinin bir tür inanç sentezi olan İslami unsurlarla karışan Şamanizm (Baksılık)'in etkisiyle ortaya çıktı̆̆ı iddia edilebilir. Kısacası Yalmavuz tipinin bir çeşidi ya da devamı olan Mıstan Kempir tipine, kökü anaerkil dönemden kalma eski Türk şaman inancındaki kadın kamlara dayanan ve onların destanlara yansıyan dev ana tipidir denilebilir.

\section{Kaynakça}

ABİLULI, Mendibay. (2013). "Muńlıq-Zarlıq" -Balalarga Arnalgan Ertegi-Kissa”. Kazak Tılı men Adebieti Dergisi, S. 2, s. 5-12.

AÇA, Mehmet. (2002). Kazak Türklerinin Destanları ve Destancılık Geleneği. Konya: Kömen Yayınları 4.

AKAN A. vd. (2008). (Ed. Kosan S. vd.), "Hikayat Risala Muńlıq, Zarlıq," Köne Epos Babalar Sözi Serisi”. C. 52, Astana: Foliant Yayınları, s. 9-83.

BASİLOV V. N. (1980). "Jalmauız Kempir”, Mifı Narodov Mira. C. 1, Moskova: Sovetskaya Ensiklopediya Yayınları.

BAYAT, Fuzuli. (2017). Türk Kültüründe Kadın Şaman. İstanbul: Ötüken Neşriyat.

DMITRIYEV, S. V. (2009). "Proishojdeniye Odnogo Demonologiçeskogo Obraza Narodov Sentral'noy Azii: Projorlivaya Staruha”. Lavrovskiy Sbornik: Materialı XXXIII SredneaziatskoKavkazskih Çteniy, St. Petersburg: MAE RAN (Kunskamera) Yayınları, s. 318-324.

GÜNGÖR, Harun. (2010). "Şamanizm”, TDV İslam Ansiklopedisi. C. 38, İstanbul: Türkiye Diyanet Vakfı Vakıf Yayınları İşletmesi, s. 325-328.

IBIRAYEV Ş. (1993). Epos Alemi: Kazak Batırlık Jırlarının Poetikası. Almatı: Gılım Yayınları. İNAYET, Alimcan. (2004). Uygur Halk Destanları I. Ankara: Türk Dil Kurumu Yayınları.

15 Şamanizm, takipçilerinin hayli çok olması ve İslam'ın topluluğun çoğunu kapsamı içine alamaması nedeniyle Kazak Türklerinin manevi hayatında XIX. yüzyılın ikinci yarısına dek varlığını korumuştur. Bk. (Kaskabasov, 2009: 86). 
İNAYET, Alimcan. (2010). Türk Dünyası Efsane ve Masallarında Bir Dev Tipi: Yalmavuz/Celmoğuz, İstanbul: Bilge Kültür Sanat Yayınları.

KALAFAT, Yaşar. (2004). Altaylar'dan Anadolu'ya Kamizm-Şamanizm. İstanbul: Yeditepe Yayınevi.

KASKABASOV, Seyit. (2009). Oyöris. Almatı: Jibek Jolı Yayınları.

KAŞGARLI, Mahmud. (1941). Divanü Lugat-Itt-Türk Tercümesi. (Çev.: Besim Atalay), C. 3, Ankara: Türk Dil Kurumu Yayınları.

KORTABAYEVA, Güljamal. (2019). Türki Mifologiyası: Oku Kuralı. Almatı: Kazak Universiteti Yayınları.

ÖGER, Adem. (2007). "Alimcan İNAYET, Türk Dünyası Efsane ve Masallarında Bir Dev Tipi: Yalmavuz/Celmoğuz, Külcüoğlu kültür Merkezi Yayınları, İzmir 2007, VIII+281 s.”. Türk Dünyası İncelemeleri Dergisi/Journal of Turkish World Studies, C. 7, S. 1, s. 219-220.

ÖZCAN, Derya (2011). "Kazak Türklerinin Muńlıq-Zarlıq Destanında Altın”, Nevşehir Üniversitesi Sosyal Bilimler Enstitüsü Dergisi, S.1, s. 30-38.

ROUX, Jean-Paul. (2015). Eski Türk Mitolojisi. (Çev.: Musa Yaşar Sağlam), Ankara: Bilge Su Yayıncilık.

SIDIKOV A. N. (2013). "Demononimı Kırgızskogo Yazıka”. Bulletin KazNU, Filology Series, S. 1-2 (141-142), s. 35-38.

TAMIR, Ferhat. (2011). "Kazaklarda Destanlar ve Er Sayın Destanı”, Kardeş Kalemler, S. 56, s. 71-76.

TIMURTAŞ, Faruk K. (2005). Tarih İçinde Türk Edebiyatı. Ankara: Akçağ Yayınları.

ULUDAĞ, Süleyman. (1995). "Erenler”, TDV İslam Ansiklopedisi. C. XI, İstanbul: Türkiye Diyanet Vakfı Vakıf Yayınları İșletmesi, s. 294-295.

YUDAHIN, K. K. (1985). Kirgizsko-Russkiy Slovar'. Frunze: Glavnaya Redaksiya Kirgizskoy Sovetskoy Ensiklopedii.

\section{İnternet Kaynakları:}

* URL-1: “Mıstan Kempir". https://adebiportal.kz/kz/characters/view/166\# (Erişim: 10.06.2020) 